\title{
Detection of Bovine Respiratory Syncytial Virus in Cell Cultures by Nested RT-PCR and Use of the Method for Virus Identification in Clinical Samples
}

\author{
V. VALENTOVÁ, K. KOVAŘČÍK, I. PŠIKAL \\ Department of Virology, Veterinary Research Institute, Brno, Czech Republic \\ Received September 10, 2002 \\ Accepted March 25, 2003 \\ Abstract
}

Valentová V., K. Kovařčík, I. Pšikal: Detection of Bovine Respiratory Syncytial Virus in Cell Cultures by Nested RT-PCR and Use of the Method for Virus Identification in Clinical Samples. Acta Vet. Brno 2003, 72: 115-122.

One-step RT-PCR and nested PCR were used to detect bovine respiratory syncytial virus (BRSV) in infected cell cultures. Specific $984 \mathrm{bp}$ and $383 \mathrm{bp}$ products, selected from gene encoding the F protein using suitable primers, were amplified and, if appropriate, reamplified. The method was further used for examination of nasal swabs and blood samples collected from animals showing signs of a respiratory disease. Lactating cows and 6-8-month-old bulls from two herds were investigated.

The infection by BRSV was confirmed by a) demonstration of specific fragments of BRSV genome in all animals showing signs of an acute disease, and b) indirectly by serological methods in convalescent animals.

Viral RNA was detected from nasal swabs and leukocytes of affected animals. The positive PCR product obtained by nested RT-PCR from RNA isolated from leukocytes was sequenced and nucleotide and amino acid homology were $97-100 \%$ and $94.5-100 \%$ respectively, when compared with sequences from the GenBank.

Considering the difficulties associated with the demonstration of BRSV in cell cultures, the amplification techniques provide an effective tool for the identification of the causative agent of bovine respiratory diseases.

Nested PCR; BRSV, F protein; diagnostics

Bovine respiratory syncytial virus is a pneumovirus of the family Paramyxoviridae causing an acute respiratory disease in cattle. BRSV mostly attacks calves, in which the infection is manifested by pyrexia, anorexia, increased respiratory rate, and dyspnoea. Infections in lactating cows, accompanied by considerable decrease in milk yield by up to $60 \%$, have also been described (Elvander 1996; Pritchard et al. 1997). Morbidity is high and death rate can reach up to $20 \%$ (Kovařčík 1997). BRSV is regarded as the major causative agent of the bovine respiratory syndrome in West European states and the USA. The agent was also demonstrated in the local cattle herds (Pospíšil et al. 1978; Kovařčík 1999), but its prevalence in the Czech Republic has not yet been studied.

The diagnosis is based on virus demonstration in cell cultures and serological methods for the demonstration of viral antigen and seroconversion. The methods used most frequently for antigen demonstration include the immunofluorescence test and the enzymatic immunosorbent assay (EIA) (Kimman et al. 1986; Krilov et al. 1988; V alarcher et al. 1999). Virus isolation is complicated by a high sensitivity of the agent and the fact that several passages are necessary before CPE develops. Tests on two blood samples collected at three-week intervals are necessary for the demonstration of seroconversion. Moreover, the interpretation of results is impeded by interaction with maternal antibodies present in blood sera of calves. Therefore, the serological methods are used mostly for the demonstration of past infections. Oberts at al. (1993) and Vilček et al. (1994) have

Address for correspondence:

MVDr. V. Valentová

Veterinary Research Institute

62132 Brno, Czech Republic
Phone: +420541321241

Fax: +420541211229

http://www.vfu.cz/acta-vet/actavet.htm 
introduced PCR techniques for rapid identification of BRSV. Published data indicate that these techniques are much more sensitive and, compared with conventional virological methods, prolong the period for which BRSV is demonstrable (West et al. 1998; Valarcher et al. 1999).

Clinical samples are collected from the respiratory tract. BRSV replicates in epithelial cells and its presence has been demonstrated in nasal and tracheal mucosae, and in bronchial, bronchiolar, and alveolar cells (Kimman et al. 1989). Nasal swabs and bronchoalveolar lavages are used most frequently as clinical materials collected from cattle. Studies on infections by human respiratory syncytial virus (HRSV) demonstrated that the agent can occur also outside the respiratory tract. Viral RNA was isolated from circulating mononuclear cells of children developing signs of a respiratory infection $\left(\mathrm{O}^{\prime}\right.$ 'D onnell et al. 1998) and HRSV genome was demonstrated by RT-PCR in blood samples collected from sick children (Rohwedder et al. 1998).

The objective of our study was to implement the PCR technology for BRSV identification in cell cultures and use it subsequently for the identification of genetic structures in clinical samples.

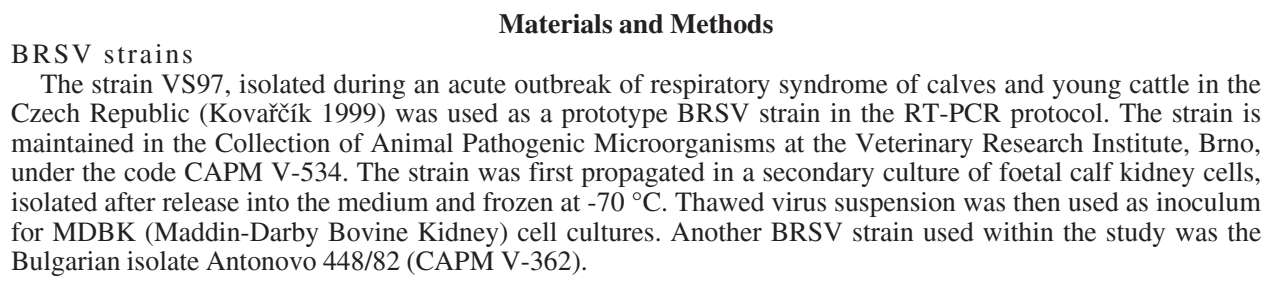

The strain VS97, isolated during an acute outbreak of respiratory syndrome of calves and young cattle in the Czech Republic (Kovařčík 1999) was used as a prototype BRSV strain in the RT-PCR protocol. The strain is maintained in the Collection of Animal Pathogenic Microorganisms at the Veterinary Research Institute, Brno, under the code CAPM V-534. The strain was first propagated in a secondary culture of foetal calf kidney cells, isolated after release into the medium and frozen at $-70^{\circ} \mathrm{C}$. Thawed virus suspension was then used as inoculum for MDBK (Maddin-Darby Bovine Kidney) cell cultures. Another BRSV strain used within the study was the Bulgarian isolate Antonovo 448/82 (CAPM V-362).

Clinical materials

Nasal swabs and peripheral blood samples were tested. The samples were collected from lactating dairy cows and from bulls aged 6 to 8 months. Only animals showing clinical signs of an acute respiratory disease were selected. Rectal temperatures of the animals ranged between 39 and $40{ }^{\circ} \mathrm{C}$. Moreover, milk yield in the cows decreased by approximately $30 \%$. Clinical samples of herd No. 1 were collected from 15 lactating dairy cows. The collected material included 5 samples of whole EDTA treated blood, 7 nasal swabs and 15 blood serum samples. Clinical samples of herd No. 2 included 7 nasal swabs.

Blood samples for PCR $(6 \mathrm{~mL})$ were collected from vena coccygea into test tubes in which $0.5 \mathrm{~mL}$ of $5 \%$ EDTA had been evaporated. Blood samples for serological examination were collected using the set Hemos in all the animals, the sampling was repeated after 3 to 4 weeks. Nasal swabs were put into $1 \mathrm{~mL}$ of the transport medium (MEM supplemented with $500 \mathrm{IU}$ of penicillin, $500 \mu \mathrm{g}$ of streptomycin, and $150 \mathrm{IU}$ of nystatin). The samples were processed immediately, or kept overnight at $4{ }^{\circ} \mathrm{C}$.

RNA for the demonstration of a specific BRSV template by nRT-PCR was isolated from pooled nasal swab and leukocyte samples. Nasal swabs were further used for virus isolation by the procedure described by Kovařčík (1999) and blood serum samples were tested for the presence of antibodies to BRSV (Kovařčík 2001).

RNA isolation

RNA was isolated from infected cell cultures and from the clinical material. All the viruses were propagated in the MDBK cell line in a growth medium which was MEM (Eagle, Sigma), supplemented with $2 \%$ of precolostral calf serum and antibiotics (penicillin $100 \mathrm{IU}$ per $1 \mathrm{~mL}$, streptomycin $0.1 \mathrm{mg}$ per $1 \mathrm{~mL}$ ). The infected cultures were incubated at $37^{\circ} \mathrm{C}$ until 80 to $100 \%$ CPE developed.

The contents of the nasal swabs were transferred into the rest of the transport medium with a syringe. Total RNA was extracted from $0.25 \mathrm{~mL}$ of this material.

EDTA-treated blood samples were mixed with $15 \mathrm{~mL}$ of the haemolytic buffer (ammonium chloride $8.3 \mathrm{~g}$, sodium hydrocarbonate $1.0 \mathrm{~g}$, EDTA $0.092 \mathrm{~g}$, bidistilled water $500 \mathrm{~mL}$ ). After $15 \mathrm{~min}$ of incubation at room temperature, leukocytes were separated by centrifugation at $2300 \mathrm{rpm}$ (Jouan BR41, rotor S40) at $4{ }^{\circ} \mathrm{C}$ for $15 \mathrm{~min}$. The sediment was resuspended in $1 \mathrm{~mL}$ of the haemolytic buffer and centrifuged in Eppendorf test tubes at 2500 rpm (Minifuge, Beckman). The supernatant was decanted and the pellet was resuspended in $1 \mathrm{~mL}$ of DPBS (Dulbecco's phosphate buffered saline, Sigma) and centrifuged again the same conditions. The separated leukocytes were enumerated using a haemocytometer. Approximately $10^{6}$ cells in $100 \mu \mathrm{L}$ of DPBS were used for the extraction of RNA.

Total RNA was isolated using the TRIzol ${ }^{\mathrm{LS}}$ reagent (Gibco, BRL) according to the manufacturer's instructions. 
The concentration and purity of the nucleic acid obtained from infected cell cultures were determined spectrophotometrically.

Primer selection and synthesis

Primers were selected according to sequences of mRNA gene for the F protein using the Clustal X (1.8) software. The following European and American strains of BRSV were used for comparative analyses: RB-94 (Acc. No. D00935); 391.2 (Acc. No. M58350); A51908 (Acc. No. M82816), and the isolate Snook (Acc. No. Y17990). The actual primer sequences were suggested by the software Primer Detective, Version 1.01. The internal primer pair sequences F51 and R51 were the same as used in RT-PCR earlier (Oberst et al. 1993). This primer pair was completed with the external primers F49 and R49. All the primers were prepared at the Laboratory of Molecular Plant Physiology of the Faculty of Sciences, Masaryk University, Brno, using the nucleotide synthesiser Experdite 8909, PerSeptive Biosystem.

nRT-PCR protocol

The nRT-PCR procedure consists of three steps: 1) synthesis of cDNA from the RNA template by reverse transcription; 2) amplification of cDNA with the external primer pair (PCR); 3) reamplification of the resulting product with the internal primer pair (nPCR, or nested PCR). In our experiments, the first two steps were joined using the Platinum Quantitative RT-PCR Thermoscript One-Step System (Gibco, BRL). The reaction was run in the Programmable Thermal Controller-100TM (MJ Research, Inc.).

The amplification reaction mixture included $25 \mu \mathrm{L}$ of the $2 \mathrm{X}$ ThermoScript Reaction mix, $1 \mu \mathrm{L}$ of the ThermoScript Plus Platinum/Tag mix, $1.0 \mu \mathrm{L}$ (40 U) of Rnazine (Promega), and the RNA sample and its volume was completed to $50 \mu \mathrm{L}$ with bidistilled water. The concentration of total RNA was up to $1 \mu \mathrm{g}$. The initial reverse transcription was run at $60^{\circ} \mathrm{C}$ for $30 \mathrm{~min}$ and at $95^{\circ} \mathrm{C}$ for the subsequent $5 \mathrm{~min}$. PCR consisted of 35 cycles of cDNA denaturation at $94{ }^{\circ} \mathrm{C}$ followed by primer annealing at $50{ }^{\circ} \mathrm{C}$ for $1 \mathrm{~min}$, and elongation at $68{ }^{\circ} \mathrm{C}$ for $1 \mathrm{~min}$. During the closing phase, the tested samples were incubated at $68{ }^{\circ} \mathrm{C}$ for $7 \mathrm{~min}$ and let to cool at $4{ }^{\circ} \mathrm{C}$. Two microlitres of the amplification product were used for reamplification. In the volume of $100 \mu \mathrm{L}$, the reaction mixture contained $73.5 \mu \mathrm{L}$ of bidistilled water, $10 \mu \mathrm{L}$ of $10 \mathrm{X}$ PCR (Promega), $1.5 \mathrm{mM}$ of magnesium chloride (Promega), $100 \mu \mathrm{M}$ of dNTP (Boehringer, Mannheim), $0.5 \mu \mathrm{M}$ of each internal primer, and $2.5 \mathrm{U}$ of Taq polymerase (Promega). The mixture was subjected to 24 cycles of temperature variations: denaturation at $94^{\circ} \mathrm{C}$ for $30 \mathrm{~s}$, annealing at $50{ }^{\circ} \mathrm{C}$ for $30 \mathrm{~s}$ and elongation at $72{ }^{\circ} \mathrm{C}$ for $30 \mathrm{~s}$. In the last cycle, the phase of elongation was prolongated to $7 \mathrm{~min}$. The resulting mixture was cooled to $4^{\circ} \mathrm{C}$.

The optimum annealing temperature was found using the Mastercycler gradient (Eppendorf). RNA of several virus species isolated most frequently from the respiratory tract were amplified and reamplified to determine the specificity of RT-PCR. The sensitivity of RT-PCR was defined as the last positive result of reamplification in tenfold dilution series of the virus suspension used for the isolation of RNA intended for the reaction. The virus was suspended in PBS (buffered physiological saline free of $\mathrm{Mg}^{++}$and $\mathrm{Ca}^{++}$. . RNA was isolated using the TRIzol ${ }^{\mathrm{LS}}$ reagent (Gibco, BRL) from $0.25 \mathrm{~mL}$ of each dilution.

PCR products were identified in $1.5 \%$ agarose gel containing ethidium bromide at $0.5 \mu \mathrm{g}$ per $1 \mathrm{~mL}$.

Sequencing

Positive PCR products were sequenced using the genetic analyser DNA ABI PRISM (Perkin Elmer) and internal primers F51, R51 in the laboratory of molecular plant physiology of the Faculty of Sciences, Masaryk University, Brno. The obtained nt and aa sequences were matched against the sequences of glycoprotein F of BRSV strains provided by the GenBank using the ClustalX 1.8 program and the data were processed with the software BioEdit (Hall 1999).

\section{Results}

Primer sequences were selected from conservative gene regions according to compared nucleotides of F protein of the BRSV strains obtained from the GenBank (391-2, Snook, RB4, and A51908). The overall homology of sequences of gene F protein was very high ranging between 96 and 99\%. External primer sequences: F49 5' -TGGAGTTAGTGTCCTTACTAGC3' (nucleotide positions 549 to 570) and R49 5'-GGCTTTCATACGTCGATCTGATGA3' (nucleotide positions 1509 to 1532), encoding a $984 \mathrm{bp}$ fragment, were selected from identical regions of the compared BRSV strains. The internal primer pair sequences corresponded to those used by Oberst et al. (1993) F51 5'-TTACCACACCCCTCAGTACA-3' (nucleotide positions 728 to 748 ) and R51 5'-GAGTGTTCTGTGACACAATG-3' (nucleotide position 1090 to 1110), encoding a 383 bp fragment.

Eleven annealing temperatures $(\mathrm{Ta})$ were tested using a temperature gradient $+/-10{ }^{\circ} \mathrm{C}$ in a total range of $40-60^{\circ} \mathrm{C}$ and temperature differences among the test tubes $2-3^{\circ} \mathrm{C}$. A gradual 
increase of PCR product concentrations could be observed simultaneous with the increase of annealing temperature Ta following application of the same volumes of amplification products onto a gel. The highest concentration was observed at $\mathrm{Ta}=60^{\circ} \mathrm{C}$, further increase of Ta to $65^{\circ} \mathrm{C}$ did not result in more effective sythesis of PCR product. The total RNA isolated from cell culture MBDK, infected with parainfluenza 3 virus, strain R-91 (isolated in the Czech Republic) and IBR virus, strain Los Angeles (CAPM, VRI, Brno, V-25) was used for determination of amplification reaction specificity in the reaction mixture. Further, total RNA isolated from blood sera of cattle infected with BVDV (L6149/99) was used in the experiments. While using those heterologous RNA templates, no amplification or reamplification product was synthesized. Control testing of the total RNA isolated from noninfected MDBK cell line and secondary cells of calf kidney gave negative reaction.

Sensitivity of the reaction was determined semiquantitatively using a 10 fold dilution of BRSV with the initial titre of $10^{4.6} \mathrm{TCID}_{50} / \mathrm{ml}$. The last positive result following reamplification was detected at virus dilution $1 \mathrm{TCID}_{50}$.

Using nRT-PCR the presence of virus template of both the strains under testing VS97 and Antonovo 448/82 was confirmed by the presence of specific products of $984 \mathrm{bp}$ and $383 \mathrm{bp}$.

Clinical samples collected from affected animals in two herds were tested by nRT-PCR. A total of 14 leukocyte samples and 1 sample of pooled nasal swab were collected from herd No.1, and 7 samples of nasal swabs were colllected from herd No. 2. The samples from herd No. 1 were taken 3 times in 4-week intervals and the following analyses were carried out: RNA isolated from 5 leukocyte samples and 1 pooled sample of nasal swab was tested; all the tested samples showed positive nPCR product. After the second sampling RNA was isolated from leukocytes of the same animals as in the first sampling; only one sample of this series was nPCR positive. At the third sampling only RNA isolated from leukocytes of the animal that showed positive nPCR during the second sampling, was tested; no PCR product was detected during this analysis. In herd No. 2 seven samples of nasal swabs from seven different animals were collected within one week. All samples were nPCR positive, one sample showed positive result already at RT-PCR (Fig. 1). Although positive result was in most cases obtained only after reamplification, the electrophoretic bands of the nested products showed marked signs of reaction.

Serological examination for the detection of antibodies to BRSV was performed by indirect ELISA (Kovařčík 2001) in samples of full blood taken during the first and second sampling from animals of herd No. 1. Seroconversion of specific antibodies to BRSV occurred in 9 animals from 15 sampling cows in the meantime of the two samplings. In other animals high antibody titres were detected as soon as during the first sampling, the level of which remained unchanged at the second sampling. From 5 cows, which were PCR positive, 4 animals showed seroconversion 1 animal did not.

The samples of nasal swabs were used for BRSV isolation in secondary cultures of calf kidney cells (Kovařčík 1999) when the individual passages were tested for the presence of virus RNA by nRT-PCR. Although the specific nPCR product was usually detected in the first two passages, the following passages were negative. We failed to isolate the virus in any of the nasal swab samples from both herds.

The positive RT-PCR products of BRSV strains VS97 and Antonovo 448/82 and positive nested products obtained by cDNA reamplification from RNA isolated from leukocytes (designated as the Studenec isolate) of affected cows were sequenced by genetic analyzer DNA ABI PRISM (Perkin Elmer) at the Laboratory of Molecular Plant Physiology of the Faculty of Sciences, Masaryk University, Brno. Internal primers F51 and R51 were used for the sequencing. The obtained nucleotide sequences (237 bp) and derived amino acid sequences (97 AMK) were compared with the sequences of gene encoding the F protein of BRSV from the GenBank. Nucleotide sequences were homologous in 97-100\%. In the 
strains RB94, Antonovo 448/82 and in the isolate Studenec $100 \%$ homology was recorded. A sequence of the strain A51098 differed most from the others (97\% homologous with RB94). Czech reference strain VS97 showed the highest homology (98.7\%) with the strains 391-2 and Snook. Comparison of amino acid sequences gave similar results when $100 \%$ homology was observed in the sequences of the strains RB94, Antonovo 448/82 and the isolate Studenec, and the highest differences gave comparison with the sequence A51908 (94.5\% homology with RB94); on the other hand 100\% homology was in the strains 3912, Snook and the Czech strain VS97.

\section{Discussion}

The conventional diagnostics of BRSV is based on isolation and detection of structural viral antigens. Virus isolation is very difficult due to its instability (Kimman et al. 1986) and several passages are necessary before the cythopathic effect develops. Therefore the immunofluorescence test and EIA were most frequently used for BRSV detection in clinical samples. Development of molecular biological methods introduced new techniques as RTPCR and hybridization of nucleic acids in the diagnostics of virus diseases. Recently, several papers have been published which compare the ability of particular diagnostic methods to detect virus in clinical samples. Both the methods, immunofluorescence test and EIA for demonstration of virus antigen, are of the same sensitivity and can be used for detection of the agents in acute stage of the disease from samples of nasal swabs and bronchoalveolar lavages. The advantage of RT-PCR is a prolonged detectable time of the virus by several days (Kimman et al. 1986; V alarcher et al. 1999).

Our goal was to develop a sensitive PCR method for virus detection in cell cultures and its subsequent use in the diagnostics of the virus from clinical samples. To obtain high specificity of amplification reactions, primers were selected from sequences of gene encoding $\mathrm{F}$ protein that showed high homology (> 95\%) among individual BRSV strains (Pastey et al. 1993). We suggested nested RT-PCR by addition of external pair of primers to the primer sequences detecting mRNA of BRSV F protein as was published previously by Oberst et al. (1993). Reaction specificity of these primers was determined by testing with templates of BRSV and HRSV strains and by a subsequent hybridization by a probe detecting inner sequences of the PCR product. Specific PCR products and hybridization signals were detected only in BRSV templates (Oberst et al. 1993). Specificity of nRT-PCR was tested with other two BRSV strains and with viruses that invade most frequently the respiratory tract of cattle (IBRV, PI3, BVDV); amplification ( $984 \mathrm{bp}$ ) and reamplification (383 bp) products were detected only in specific templates. Identity of the PCR products was subsequently confirmed by their sequencing. The use of nested PCR enabled to detect up to $1 \mathrm{TCID}_{50}$, which is comparable to results of other authors (Vilček et al. 1994). The advantage of the nested PCR compared with simple PCR involves the ability to detect small amount of the virus in clinical materials. It was also confirmed by our results of clinical sample examinations when most of the positive PCR products were detected at reamplification only (Plate IX, Fig. 1). Vilček et al. (1994) detected positive PCR products using F protein specific PCR in single PCR. This difference could be due to sampling procedure. Connection of the first two steps i.e. transcription and amplification using Platinum Quantitative RT-PCR ThermoScript ${ }^{\text {TM }}$ One-Step System (Gibco BRL) resulted in less laboriousness of the method and minimization of the contamination risk between individual steps of nRT-PCR.

Nasal swabs are most frequently used for laboratory diagnosis of BRSV. However, detection of the virus in these samples can be influenced by low count of infected cells in the collected specimens. This obstacle is usually overcome by bronchoalveolar lavage (BAL) of lungs when the suitable material for examination is obtained from bronchi and bronchioli. Bronchoalveolar lavages increased the detectability of BRSV and prolonged the 
interval for virus detection (Kimman et al. 1986; Valarcher et al. 1999). As sample collection by lavage cannot be commonly practised, our investigations were oriented to demonstration of BRSV genome in nasal swab samples collected from animals in acute stage of the disease when detection of the virus is most reliable (Kimman et al. 1986).

Examinations of clinical samples included virus demonstration in blood. Detection of BRSV was based on data published on the related HRSV Studies on HRSV showed that in vitro the virus propagates in blood monocytes and alveolar macrophages (D omurat et al. 1985; Midulla et al. 1989). Viral mRNA was isolated from circulating mononuclear cells of children developing signs of respiratory infection (O'D onnell et al. 1989) and HRSV genome was demonstrated by PCR in blood samples (Rohwedder et al. 1998). BRSV propagated in vitro in peripheral lymphocytes and monocytes of sheep and cattle (Keles et al. 1998; Sharma and Woldehiwet 1996b) and was detected in peripheral lymphocytes of experimentally infected lambs (Sharma and Woldehiwet 1996a).

The developed nRT-PCR enabled to detect viral RNA in nasal swabs and leukocyte samples of animals with clinical symptoms. Positive PCR products were detected in all samples but one of nasal swabs only after reamplification which suggests of low concentration of the virus in the examined samples. Identity of the nested products was confirmed by sequencing. Seroconversion of specific antibodies to BRSV in PCR positive animals was determined in four animals of herd No.1 from which pair samples of blood sera were obtained; in the remaining one animal high titre of antibodies were detected already at the first sampling, the level of which did not change significantly at the second sampling. It can be explained by blood collection in later, the convalescent stage of the infection, when specific antibodies had already been formed.

Viral RNA was detected in peripheral blood leukocytes during the acute stage of the infection and in one dairy cow even 4 weeks later. Our results do show neither the duration of viremia, nor whether it is a long-term persistence of intact BRS virus in blood. Demonstration of BRSV in peripheral leukocytes suggests a possible persistence of the virus in immune cells. Simultaneous with virus identification in clinical materials, experiments with virus isolation from cell cultures were carried out by conventional procedures (Kovařčík 1999). We failed to isolate the virus from any of the samples, though its presence in the samples was confirmed by nRT-PCR. In the first passages of few samples we succeeded to detect small amounts of the virus (positive reamplification product) but the following passages were negative. It might be explained by the presence of incomplete virus particles with intact viral RNA in clinical samples or virus neutralization by specific antibodies. These experiments show low reliability of BRSV detection by isolation in cell cultures. It can be the reason why only two BRSV strains have been isolated so far in the Czech Republic (Pospíšil et al. 1978; Kovařčík 1999).

We have developed a sensitive nested RT-PCR for the detection of BRSV in infected cell cultures and clinical samples. Detection of the virus in peripheral blood leukocytes suggests a possible persistence of the virus in cells of the immune system.

\section{Detekce bovinního respiračního syncytiální viru v buněčných kulturách pomocí nRT-PCR a její využití při identifikaci viru z klinického materiálu.}

Byla zavedena metoda využívající one-step-RT PCR a nested PCR k identifikaci bovinního respiračního syncytiálního viru (BRSV) v infikovaných buněčných kulturách. Pomocí primerů, které byly vybrány z genu pro F protein, byly amplifikovány, respektive reamplifikovány specifické produkty o velikosti 984 bp a 383 bp. Tato metoda byla dále použita pro vyšetření klinických vzorků nosních výtěrů a krve odebraných od zvířat s respiračními příznaky onemocnění. Byly vyšetřovány vzorky od laktujících krav a býků stáří 6-8 měsíců ze dvou chovů. 
Infekce virem BRSV byla potvrzena a) průkazem specifických fragmentů genomu BRSV u všech akutně nemocných zvířat, b) nepřímo pomocí sérologie u rekonvalescentních zvířat.

Pozitivní PCR produkty získané nRT-PCR amplifikací RNA izolované z leukocytů byly sekvenovány, nukleotidové sekvence byly 97-100\% a aminokyselinová 94.5-100\% shodné se sekvencemi z GenBank. Vzhledem k obtížím spojených s průkazem BRSV izolací v buněčných substrátech, poskytují aplifikační techniky vhodný nástroj pro stanovení původce respiračního onemocnění skotu.

\section{Acknowledgements}

The study was supported by the Ministry of Agriculture of the Czech Republic (grant No. M 03-99-01) and by the Grant Agency of the Czech Republic (grant No. GP524/01/D055).

\section{References}

DOMURAT, F, ROBERTTS, NJ JR, WALSH, EE, DAGAN, R 1985: Respiratory syncytial virus infection of human mononuclear leukocytes in vitro and in vivo. J Infect Dis 152: 895-902

ELVANDER, M 1996: Severe respiratory disease in dairy cows caused by infection with bovine respiratory syncytial virus. Vet Rec 138: 101-105

HALL, TA 1999: BioEdit: a user-friendly biolocigal sequnce aligment editor and analysis program for Windows95/98/NT. Nucleic Acids Symp Ser 41: 95-98

KELES, I, WOLDEHIWET, Z, MURRAY, R D 1998: Replication of bovine respiratory syncytial virus in bovine and ovine peripheral blood lymphocytes and monocytes and monocytic cell lines. Vet Microbiol 61: 237-248

KIMMAN, TG, ZIMMER, GM, STRAVER, PJ, DE LEEUW, PW 1986: Diagnosis of bovine respiratory syncytial virus infections improved by virus detection in lung lavage samples. Am J Vet Res 47: 143-147

KIMMAN, TG, STRAVER, PJ, ZIMMER, GM 1989: Pathogenesis of naturally acquired bovine respiratory syncytial virus infection in calves: morphologic and serologic findings. Am J Vet Res 50: 684-693

KOVAŘČÍK, K 1997: Respiratory syncytial viruses: pathogenesis, immunology and disease prevention. Vet Med Czech 42: 265-278

KOVAŘČÍK, K 1999: Isolation of bovine respiratory synsytial virus during an outbreak of acute respiratory disease in calves. Vet Med- Czech 44: 121-127

KOVAŘČÍK, K 2001: The development and application of an indirect ELISA test for the detection of antibodies to bovine respiratory syncytial virus in blood serum. Vet Med -Czech 46: 29-34

KRILOV, LR, MARCOUX, L, ISENBERG, HD 1988: Comparison of three enzyme-linked immunosorbent assays and a direct fluorescent-antibody test for detection of respiratory syncytial virus antigen. J Clin Microbiol 26: 377-379

MIDULlA, F, HUANG, YT, GILBERT, IA, CIRINO, NM, MCFADDEN, ER Jr, PANUSKA, JR 1989: Respiratory syncytial virus infection of human cord and adult blood monocytes and alveolar macrophages. Am Rev Respir Dis 140: 771-777

O'DONNELL, DR, MCGARVEY, MJ, TULLY, JM, BALFOUR-LYNN, IM, OPENSHAW, PJ 1998: Respiratory syncytial virus RNA in cells from the peripheral blood during acute infection. J Pediatr 133: $272-$ 274

OBERST, RD, HAYS, MP, HENNESSY, KJ, STINE, LC, EVERMANN, JF. KELLING, CL 1993: Identifying bovine respiratory syncytial virus by reverse transcription-polymerase chain reaction and oligonucleotide hybridizations. J Clin Microbiol 31: 1237-1240

PASTEY, MK, SAMAL, SK 1993: Structure and sequence comparison of bovine respiratory syncytial virus fusion protein. Virus Res 29: 195-202

POSPÍŠIL, Z, MENŠÍK, J, VALÍČEK, L 1978: Isolation and identification of bovine respiratory syncytial virus in Czechoslovakia. Acta Vet Brno 47: 79-86

PRITCHARD, G, FISHWICK, J, 1997: Bovine respiratory syncytial virus infection in lactating cows. Vet Rec 141: $131-132$

ROHWEDDER, A, KEMINER, O, FOSTER, J, SCHNEIDER, K, SCHNEIDER, E, WERCHAU H. 1998: Detection of respiratory syncytial virus RNA in blood of neonates by polymerase chain reaction. J Med Virol 54: $320-327$

SHARMA, AK, WOLDEHIWET, Z 1996a: Antigens of bovine respiratory syncytial virus in peripheral blood lymphocytes of experimentally infected lambs. Vet Immunol Immunopathol 50: 93-104

SHARMA, AK, WOLDEHIWET, Z 1996b: Replication of bovine respiratory syncytial virus in ovine peripheral blood lymphocytes and monocytes in vitro. Vet Microbiol 48: 125-134

THOMPSON, JD, GIBBON, TJ, PLEWNIAK, F, JEANMOUGIN, F, HIGGINS, DG 1997: The CLUSTAL_X windows interface: flexible strategies for multiple sequence alignment aided by quality analysis tools. Nuclei Acids Res 25: 4876-4882

VALARCHER, JF, BOURHY, H, GELFI, J, SCHECHER, F 1999: Evaluation of a nested reverse transcription- 
PCR assay based on the nucleoprotein gene for diagnosis of spontaneous and experimental bovine respiratory syncytial virus infections. J Clin Microbiol 37: 1858-1862

VILČEK, S, ELVANDER, M, BALLAGI-PORDANY, A, BELAK, S 1994: Development of nested PCR assays for detection of bovine respiratory syncytial virus in clinical samples J Clin Microbiol 32: 2225-2231

WEST, K, BOGDAN, J, HAMEL, A, NAYAR, G, MORLEY, PS, HAINES, DM, ELLIS JA 1998: A comparison of diagnostic methods for the detection of bovine respiratory syncytial virus in experimental clinical specimens. Can J Vet Res 62: 245-250 
Plate IX

Valentová V. et. al.: Detection of... pp. 115-122

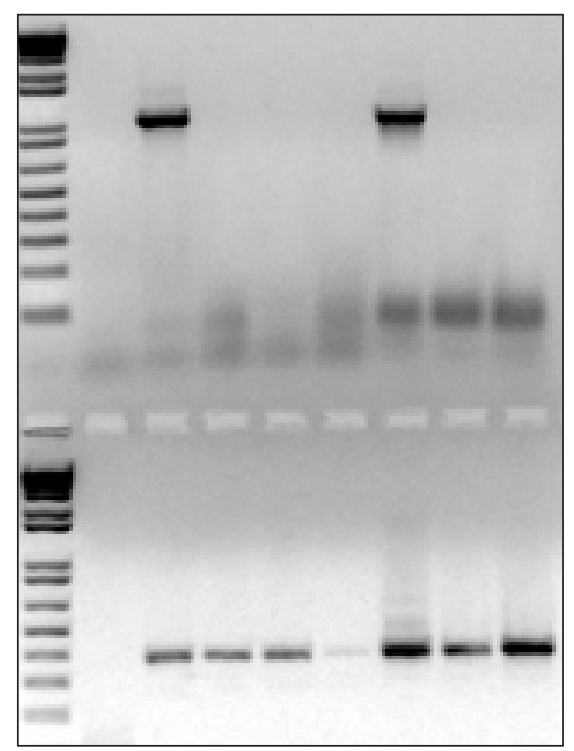

Fig. 1: Results of electrophoresis (negative) of RT-PCR (A) and re-amplification (B) products. Legends: Column 1 - RNA of MDBK cells; column 2 - RNA of MDBK cells infected by BRSV VS 97; columns 3, 4 , 5 - RNA in leukocytes of cows Nos. 1, 2, and 4; columms 6,7,8, - RNA in nasal swabs of bulls Nos. 5, 3, 4, MM - molecular marker $1 \mathrm{~Kb}$ Plus DNA Ladder (Gibco BRL) 